\title{
Thrombotic Microangiopathy, Hemolytic Uremic Syndrome, and Thrombotic Thrombocytopenic Purpura Following Hump-nosed Pit Viper (Genus: Hypnale) Envenoming in Sri Lanka
}

\author{
RMMK Namal Rathnayaka, MBBS, MA, MSc in Medical Tox., Dip. in Tox., Dip. in OH\& $S^{1,2,3}$; \\ PE Anusha Nishanthi Ranathunga, MBBS $^{4}$; Senanayake AM Kularatne, MBBS, MD, MRCP (UK), FRCP (Lond) ${ }^{5}$ \\ ${ }^{1}$ Department of Veterinary Pathobiology, Faculty of Veterinary Medicine and Animal Science, University of Peradeniya, Peredeniya, Sri Lanka; \\ ${ }^{2}$ Intensive Care Unit/Anaesthesia, Provincial General Hospital, Ratnapura, Sri Lanka; ${ }^{3}$ Postgraduate Institute of Medicine (Clinical \\ Pharmacology and Therapeutics), University of Colombo, Colombo, Sri Lanka; ${ }^{4}$ Medical Unit, Provincial General Hospital, Ratnapura, \\ Sri Lanka; ${ }^{5}$ Faculty of Medicine, University of Peradeniya, Peredeniya, Sri Lanka.
}

\begin{abstract}
Thrombotic microangiopathy (TMA), which includes the spectrum of hemolytic uremic syndrome and thrombotic thrombocytopenic purpura, is an uncommon complication of hump-nosed pit viper envenomation. We describe 4 cases of TMA following hump-nosed pit viper (Hypnale spp) bites in Sri Lanka. The first case is a typical TMA that spontaneously resolved with supportive treatments. The second and third cases are related to hemolytic uremic syndrome complicated with acute kidney injury that required hemodialysis. The fourth case is thrombotic thrombocytopenic purpura associated with acute kidney injury that required hemodialysis and therapeutic plasma exchange. For each patient we describe the circumstances of the bite, clinical features, laboratory findings, and management.
\end{abstract}

Keywords: snakebites, acute kidney injury, microangiopathic haemolysis, coagulopathy, Sri Lanka

\section{Introduction}

Hump-nosed pit vipers of the genus Hypnale are the most common cause of venomous snakebites in Sri Lanka, ${ }^{1}$ accounting for 22 to $77 \%$ of all snakebites. ${ }^{2,3}$ In Sinhala the hump-nosed viper is known as Kunakatuwa, denoting the necrotic effect of its bite, or Polonthelissa, referring to the viper with an upturned snout ("hump"). Recent taxonomic revision has identified 3 species of Hypnale: $H$ hypnale, $H$ zara, and $H$ nepa. The latter 2 are found only in Sri Lanka, and the former is found in both Sri Lanka and the region of Western Ghats of India. ${ }^{4}$ Although its bites frequently only cause local envenomation, such as local pain, swelling, blistering at the site of the bite, and local tissue

Corresponding author: RMMK Namal Rathnayaka, MBBS, MA, MSc in Medical Tox., Dip. in Tox., Dip. in OH\&S, No. 11, Flower Road, New Town Housing Scheme 01, New Town, Ratnapura, Sri Lanka; e-mail: namalrath10@yahoo.com.

Submitted for publication May 2018.

Accepted for publication October 2018. necrosis, ${ }^{5-8}$ the World Health Organization has categorized $H$ hypnale as a snake in category I of medical importance, requiring administration of antivenom. ${ }^{9}$ This is because hump-nosed pit viper bites can cause severe systemic envenomation that often includes coagulopathy, ${ }^{10}$ acute kidney injury (AKI), ${ }^{11}$ chronic kidney disease, ${ }^{12,13}$ thrombotic microangiopathy (TMA) ${ }^{8,14}$ systemic bleeding, ${ }^{7,15}$ myocardial infarction, ${ }^{16}$ ischemic strokes, ${ }^{17}$ atrial fibrillation, and cardiac arrest. ${ }^{18}$ These manifestations may be fatal. ${ }^{7,13,18} \mathrm{We}$ report a case series of TMA that includes a spectrum of hemolytic uremic syndrome (HUS) to thrombotic thrombocytopenic purpura after hump-nosed pit viper (Hypnale spp) envenomation in Sri Lanka.

\section{Case reports}

CASE 1

A 60-y-old woman was transferred from a local hospital for further management of high serum creatinine level (3.46 mg. $\mathrm{dL}^{-1}$ [normal $\left.0.4-1.2 \mathrm{mg} \cdot \mathrm{dL}^{-1}\right]$ ) after snakebite 
$2 \mathrm{~d}$ earlier. She was educated up to grade 5 and lives in a remote village in southcentral Ratnapura, Sri Lanka. She was bitten in the left foot by a snake while she was working in a home garden at around 1430. The snake was identified as a hump-nosed pit viper by the attending medical officer at the local hospital. Initially she was given native treatments of both local application and ingestion of herbal decoction because her husband was an Ayurvedic physician. Because she experienced vomiting and local pain at the bitten site, she was admitted to the local hospital.

On admission to the tertiary care center, she had no bleeding and her urine output was normal. On examination she was afebrile but had moderate swelling of the bitten foot (Figure 1). Her blood pressure (BP) was $110 / 70 \mathrm{~mm} \mathrm{Hg}$, her pulse rate was 76 beats. $\mathrm{min}^{-1}$, and both lung fields were clear. Twenty-minute whole blood clotting test (WBCT20) was normal (WBCT20 $<20 \mathrm{~min}$, done in a borosilicate tube without a control sample) on admission. Other investigations were white blood cell count $\left(9.5 \times 10^{3} \cdot \mu \mathrm{L}^{-1}\right)$, neutrophils $(75 \%)$, lymphocytes $(19 \%)$, platelets $\left(105 \times 10^{3} \cdot \mu \mathrm{L}^{-1}\right)$, hemoglobin $\left(9.5 \mathrm{~g} \cdot \mathrm{dL}^{-1}\right), \quad \mathrm{Na}^{+} \quad\left(124 \mathrm{mmol} \cdot \mathrm{L}^{-1}\right), \quad \mathrm{K}^{+}$ $\left(3.6 \mathrm{mmol} \cdot \mathrm{L}^{-1}\right)$, serum creatinine $\left(294 \mu \mathrm{mol} \cdot \mathrm{L}^{-1}\right)$, blood urea $\left(17.4 \mu \mathrm{mol} \cdot \mathrm{L}^{-1}\right)$, serum glutamic-oxaloacetic transaminase $\left(29 \mathrm{U} \cdot \mathrm{I}^{-1}\right)$, serum glutamic-pyruvic transaminase $\left(16 \mathrm{U} \cdot \mathrm{I}^{-1}\right)$, alkaline phosphatase $\left(244 \mathrm{U} \cdot \mathrm{I}^{-1}\right)$, total bilirubin $\left(17.7 \mu \mathrm{mol} \cdot \mathrm{L}^{-1}\right)$, direct bilirubin $\left(6.3 \mu \mathrm{mol} \cdot \mathrm{L}^{-1}\right)$, prothrombin time $(12 / 12$,$) international$

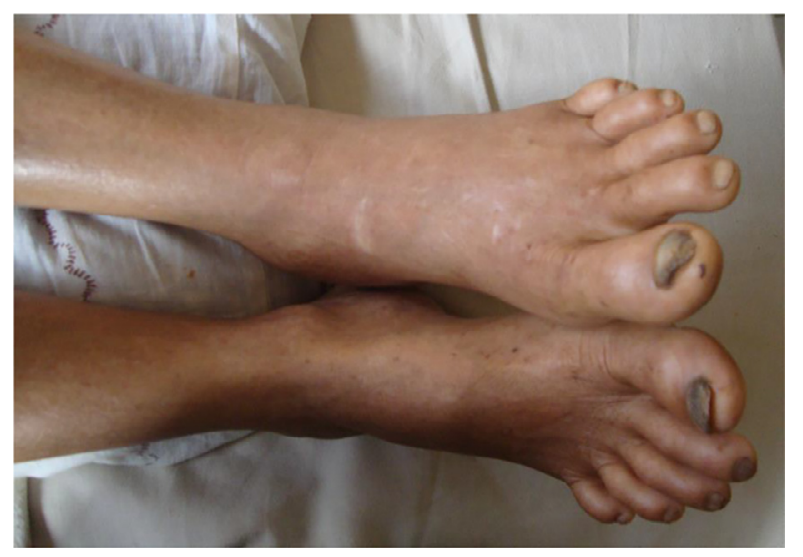

Figure 1. Bite site, left foot. Patient described in case 1. normalized ratio (1.03), and random blood sugar (4.9 $\left.\mathrm{mmol} \cdot \mathrm{L}^{-1}\right)$. Urine albumin was $1+$ and the electrocardiogram was normal. However, the blood picture showed fragmented erythrocytes $>4$ in high-power field, suggestive of microangiopathic hemolytic anemia (MAHA).

The patient was kept in a position with the left leg elevated and received other supportive treatments. Oral fluid intake of $80 \mathrm{~mL} \cdot \mathrm{h}^{-1}$ was maintained, and urine output was monitored. Her fluid balance and renal biochemistry during hospitalization are described in Table 1. On day 4 (day 7 after snakebite) she was discharged because her urine volume had normalized and her creatinine level had decreased. On follow-up, her serum creatinine (day 10) was $129 \mu \mathrm{mol} \cdot \mathrm{L}^{-1}$ (normal $60-120 \mu \mathrm{mol} \cdot \mathrm{L}^{-1}$ ), hemoglobin was $10.6 \mathrm{~g} \cdot \mathrm{dL}^{-1}, \mathrm{~K}^{+}$level was $4 \mathrm{mmol} \cdot \mathrm{L}^{-1}$, and $\mathrm{Na}^{+}$level was $137 \mathrm{mmol} \cdot \mathrm{L}^{-1}$.

\section{CASE 2}

A 74-y-old healthy male farmer was bitten on his left foot near the base of the great toe by a hump-nosed pit viper while he was walking in his home garden at about 2130 . He was admitted to the emergency treatment unit. He had not received formal schooling and lives in a remote village in northwest Ratnapura, Sri Lanka. He attempted first aid by washing the site of the bite with soap and water and then applied a ligature above the bitten site for $30 \mathrm{~min}$. On admission he had severe local pain with reduced urine output. On examination there was moderate swelling at the site of the bite and 2 fang punctures. His BP was 210/120 mm $\mathrm{Hg}$, pulse rate was 92 beats $\cdot \mathrm{min}^{-1}$, and both lung fields were normal. He was started on tramadol $50 \mathrm{mg}$ twice daily with paracetamol $1 \mathrm{~g}$ thrice daily, glyceryl trinitrate infusion $50 \mathrm{micrograms} \cdot \mathrm{min}^{-1}$, and prazosin $1 \mathrm{mg}$ thrice daily for high BP. His WBCT20, which was done in a borosilicate tube without a control sample on admission and then every $6 \mathrm{~h}$ for $24 \mathrm{~h}$, was normal. On day 2, a blister developed on the bitten site (Figure 2). $\mathrm{He}$ was anuric; blood urea and serum creatinine level were elevated. Blood picture showed microangiopathic hemolysis. His laboratory findings are described in Table 2.

Table 1. Input-output balance with renal biochemistry in patient described in case 1

\begin{tabular}{lccccc}
\hline Day & Creatinine $\left(\mu \mathrm{mol} \cdot \mathrm{L}^{-1}\right)$ & Blood urea $\left(\mathrm{mmol} \cdot \mathrm{L}^{-1}\right)$ & Serum $^{+}\left(\mathrm{mmol} \cdot \mathrm{L}^{-1}\right)$ & Input $(\mathrm{mL})$ & Output $\left(\mathrm{mL} \cdot \mathrm{h}^{-1}\right)$ \\
\hline 1 & 294 & 17 & 3.6 & 2450 & 46 \\
2 at 0800 & 313 & 15 & 3.5 & 2970 & 56 \\
2 at 1400 & 309 & 14 & 3.8 & 2970 & 56 \\
3 & 287 & 15 & 3.3 & 3570 & 82 \\
\hline
\end{tabular}




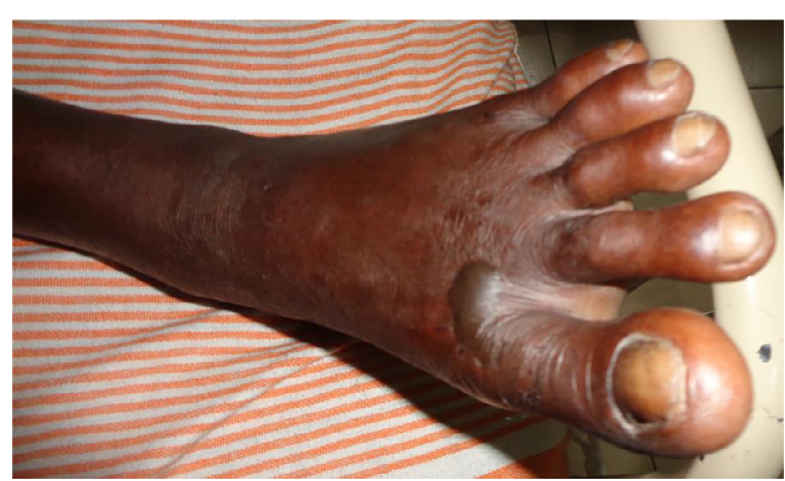

Figure 2. Blister appeared on bitten site on day 2 after snakebite in case 2 patient.

The first cycle of hemodialysis was done on day 3 after snakebite, and subsequently 2 cycles were carried out. On day 9, his lactate dehydrogenase level was $1079 \mathrm{U} \cdot \mathrm{L}^{-1}$ (normal $\leq 450 \mathrm{U} \cdot \mathrm{L}^{-1}$ ). On day 10 , the patient was transferred to National Hospital Sri Lanka for nephrology referral because he remained anuric. He recovered after several cycles of hemodialysis and plasmapheresis at National Hospital Sri Lanka. Using the key described by Maduwage et $\mathrm{al}^{4}{ }^{4}$ the species of offending snake was identified by the corresponding author as $H$ hypnale (Figure 3 ).

\section{CASE 3}

A 57-year-old, previously healthy man was transferred from a local hospital for the management of a hump-nosed viper bite, with the killed specimen of the snake. He was a tea leave plucker who lives in a remote village in westcentral Ratnapura, Sri Lanka, and is educated up to grade 3. He was bitten on the left index finger while working in the tea estate at around 1130 and was admitted to the local hospital by about 1430 . He was then transferred to Provincial General Hospital at about 0230 on the following day ( $15 \mathrm{~h}$ after the snakebite). No first aid or herbal decoction treatment was attempted before he arrived at the hospital.

On admission to the medical ward his urine output was normal, and he had severe local pain and swelling with multiple blisters on his left upper limb (Figure 4). There was no necrosis or blistering at the site of the bite. On admission his serum creatinine level was elevated (Table 3). On the same day he was transferred to the

Table 2. Laboratory findings of patient described in case 2

\begin{tabular}{|c|c|c|c|c|c|c|c|c|c|c|}
\hline \multirow[b]{2}{*}{ Investigation } & \multirow[b]{2}{*}{ Reference range } & \multicolumn{9}{|c|}{ Day } \\
\hline & & 1 & 2 & 3 & 4 & 5 & 6 & 7 & 8 & 9 \\
\hline $\mathrm{WBC}\left(\times 10^{3} \cdot \mu \mathrm{L}^{-1}\right)$ & $4-10$ & & 14 & 22 & 25 & 22 & 21 & 19 & & 16 \\
\hline Neutrophils (\%) & $50-70$ & & 89 & 91 & 91 & 87 & 88 & 81 & & 80 \\
\hline Lymphocytes (\%) & $20-40$ & & 7 & 3 & 4 & 3 & 3 & 3 & & 5 \\
\hline Neutrophil count $\left(\times 10^{3} \cdot \mu \mathrm{L}^{-1}\right)$ & $2-7$ & & 12 & 20 & 21 & 18 & 19 & 15 & & 12 \\
\hline Lymphocyte count $\left(\times 10^{3} \cdot \mu \mathrm{L}^{-1}\right)$ & $0.8-4$ & & 1 & 0.7 & 1 & 0.8 & 0.7 & 0.5 & & 0.8 \\
\hline Platelets $\left(\times 10^{3} \cdot \mu \mathrm{L}^{-1}\right)$ & $150-450$ & & 219 & 111 & 109 & 142 & 135 & 178 & & 225 \\
\hline $\mathrm{Hb}\left(\mathrm{g} \cdot \mathrm{dL}^{-1}\right)$ & $11-16$ & & 12.6 & 10.8 & 11.2 & 10.2 & 9.8 & 9.3 & & 8.9 \\
\hline RBC count $\left(\times 10^{6} \cdot \mu \mathrm{L}^{-1}\right)$ & $4-6$ & & 4 & 3.4 & 3.6 & 3.2 & 3.1 & 3 & & 2.9 \\
\hline $\operatorname{PCV}(\%)$ & $37-54$ & & 38 & 31 & 32 & 29 & 28 & 28 & & 27 \\
\hline $\mathrm{PT}(\mathrm{s})$ & $10-15$ & & $12 / 12$ & & & & & & & $17.7 / 12$ \\
\hline INR & $1-1.4$ & & 1 & & & & & & & 1.5 \\
\hline $\operatorname{APTT}(\mathrm{s})$ & $25-30$ & & $39 / 25$ & & & & & & & $28 / 25$ \\
\hline $\mathrm{Na}^{+}\left(\mathrm{mmol} \cdot \mathrm{L}^{-1}\right)$ & $135-145$ & 141 & 137 & 137 & 136 & 134 & 132 & 134 & 133 & 148 \\
\hline $\mathrm{K}^{+}\left(\mathrm{mmol} \cdot \mathrm{L}^{-1}\right)$ & $3.5-4.5$ & 4.5 & 4.4 & 4.3 & 5.1 & 4.8 & 4.6 & 4.4 & 4.9 & 4.7 \\
\hline Creatinine $\left(\mu \mathrm{mol} \cdot \mathrm{L}^{-1}\right)$ & $60-115$ & 118 & 254 & 297 & 441 & 518 & 513 & 538 & 645 & 362 \\
\hline SGOT (AST) (U.I $\left.{ }^{-1}\right)$ & $0-35$ & & 29 & & & & & & & \\
\hline SGPT (ALT) $\left(\mathrm{U}^{-\mathrm{I}^{-1}}\right)$ & $0-45$ & & 15 & & & & & & & \\
\hline MCV (fL) & $80-100$ & & 95 & 91 & 95 & 93 & 93 & 93 & & 90 \\
\hline $\mathrm{MCH}(\mathrm{Pg})$ & $27-34$ & & 31 & 32 & 31 & 33 & 32 & 31 & & 30 \\
\hline $\operatorname{MCHC}\left(\mathrm{g} \cdot \mathrm{dL}^{-1}\right)$ & $32-36$ & & 33 & 35 & 33 & 35 & 35 & 34 & & 35 \\
\hline MPV (fL) & $7.8-11$ & & 7.3 & 8.7 & 8.8 & 9.1 & 9 & 8.4 & & 8.2 \\
\hline
\end{tabular}

WBC, white blood cells; Hb, hemoglobin; RBC, red blood cells; PCV, packed cell volume; PT, prothrombin time; INR, international normalized ratio; APTT, activated partial thromboplastin time; SGOT, serum glutamic-oxaloacetic transaminase; AST, aspartate aminotransferase; SGPT, serum glutamic-pyruvic transaminase; ALT, alanine aminotransferase; MCV, mean corpuscular volume; $\mathrm{MCH}$, mean corpuscular hemoglobin; MCHC, mean corpuscular hemoglobin concentration; MPV, mean platelet volume. 

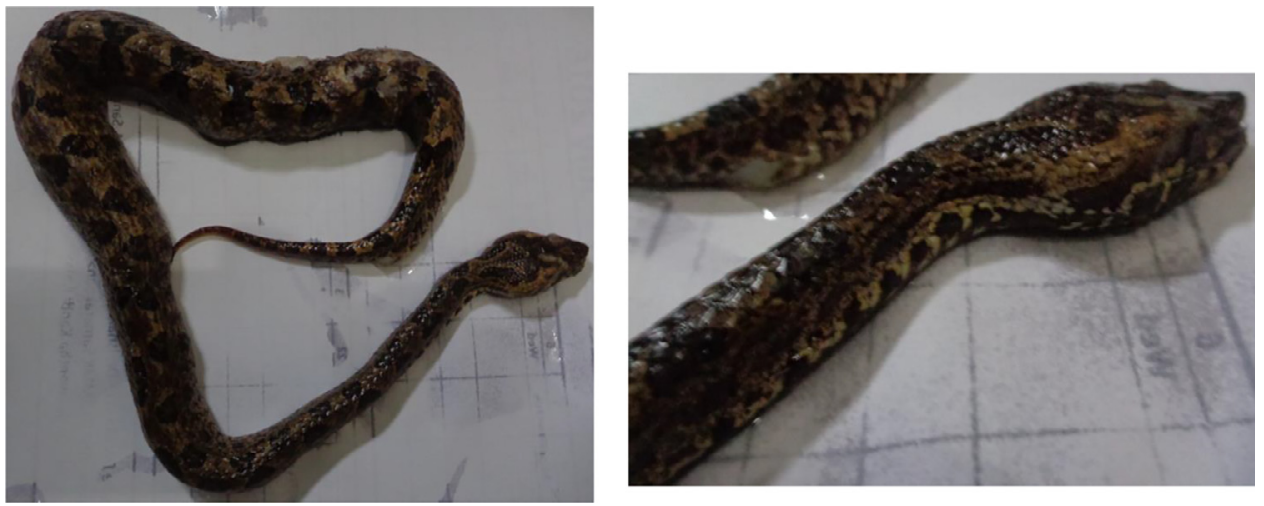

Figure 3. Snake responsible for the bite described in case 2. A female hump-nosed pit viper (Hypnale hypnale) with total length of $455 \mathrm{~mm}$, head length $24 \mathrm{~mm}$, tail length $67 \mathrm{~mm}$, and snout to vent length $388 \mathrm{~mm}$, from Parakaduwa, a remote village in Ratnapura district $\left(06^{\circ} 40^{\prime} \mathrm{N} 80^{\circ} 24^{\prime} \mathrm{E}\right.$;

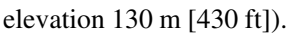

surgical unit for further management of blisters; there, he developed reduced urine output associated with further elevation of creatinine.

After $4 \mathrm{~d}$ in the surgical unit, the patient was transferred to the medical unit for management of AKI. Microscopy of peripheral blood smear done on day 4 after snakebite showed fragmented red blood cells, polychromatics, and acanthocytes, suggestive of microangiopathic hemolysis. On day 5, the patient was transferred to the intensive care unit for hemodialysis and plasmapheresis. He was then returned to the medical unit. Altogether, 2 cycles of hemodialysis and 1 cycle of therapeutic plasma exchange were done.

Gradually he produced a normal amount of urine, and his blood urea and creatinine levels decreased (Figure 5). With 1 cycle of therapeutic plasma exchange, his platelet count increased (Figure 6). However, his prothrombin time/international normalized ratio were gradually increasing, with the highest value (25 seconds/2.1) observed on day 6 (Figure 7). Fresh frozen plasma (FFP) was administered during plasmapheresis. His WBCT20, done in a borosilicate tube without a control sample on admission and then every $6 \mathrm{~h}$ for $48 \mathrm{~h}$, was normal. He was discharged on day 17, when serum creatinine level was $445 \mu \mathrm{mol} \cdot \mathrm{L}^{-1}$, and followed up at the clinic. His day 22 creatinine was $241 \mu \mathrm{mol} \cdot \mathrm{L}^{-1}$, and serum electrolytes were normal $\left(\mathrm{K}^{+} 4.1 \mathrm{mmol} \cdot \mathrm{L}^{-1}\right.$ and $\left.\mathrm{Na}^{+} 138 \mathrm{mmol} \cdot \mathrm{L}^{-1}\right)$. Using a published key, ${ }^{4}$ the species of offending snake was identified by the corresponding author as $H$ hypnale (Figure 8).

\section{CASE 4}

A 55-year-old female patient presented to the medical unit after being bitten by a snake. The killed specimen was identified as $H$ hypnale (Figure 9 ) by the corresponding author using a published key. ${ }^{4}$ The patient was known to have type 2 diabetes with dyslipidemia and was noncompliant with prescribed medication.

The patient resides in a remote village in northwest Ratnapura, Sri Lanka. While spreading washed clothes in the home garden, the snake bit her right foot at around 1200. The bitten site was washed with soap and water, but a ligature was not applied. She was admitted to the hospital around 1245.

On admission she had severe pain and swelling involving the bitten site (Figure 10). Bleeding from the site of bite was not observed, and her WBCT20 was normal on admission (the test was done in a borosilicate tube without a control sample). From day 2 to day 6 , she experienced drowsiness, but her consciousness was not affected (Glasgow coma scale -15/15]. Laboratory findings are shown in Table 4.

A second WBCT20 performed $4.5 \mathrm{~h}$ after the snakebite remained nonclotted for $48 \mathrm{~h}$. Therefore, she was transfused 2 packs FFP twice daily until WBCT20 was normal on day 2 of the snakebite. She reported abdominal pain and vomiting associated with reduced urine output at around $12 \mathrm{~h}$ after the snakebite. Microscopy of her peripheral blood smear done around $20 \mathrm{~h}$ after the snakebite showed microangiopathic hemolysis (Figure 11). The first cycle of hemodialysis was done on day 4 after snakebite, and subsequently 5 cycles of hemodialysis were carried out (Figure 5). One cycle of plasmapheresis was performed on day 4 after snakebite (Figure 6).

During her hospital stay, her BP was controlled with amlodipine $5 \mathrm{mg}$ twice daily and prazosin $1 \mathrm{mg}$ thrice daily; subcutaneous soluble insulin $15 \mathrm{U}$ was given thrice a day for increased blood sugar levels. She was discharged on day 15 after her urine output normalized, and follow-up with the nephrology unit was arranged. Four months after the snakebite her serum creatinine 


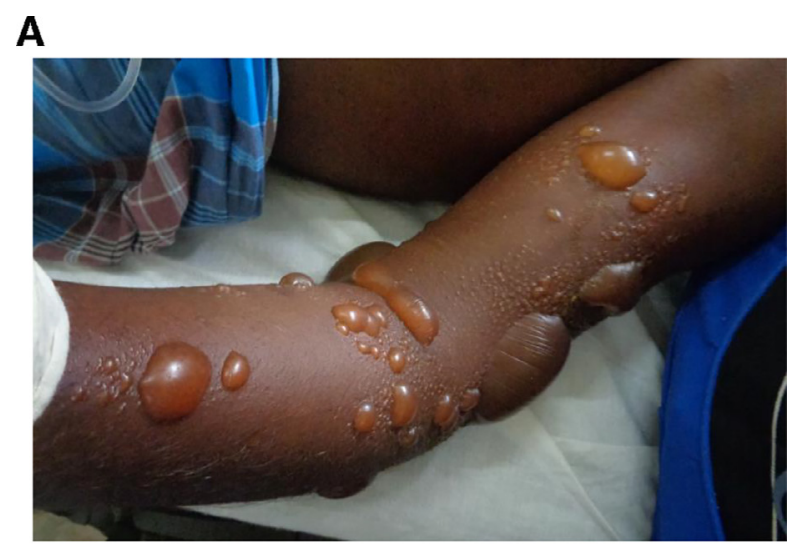

B

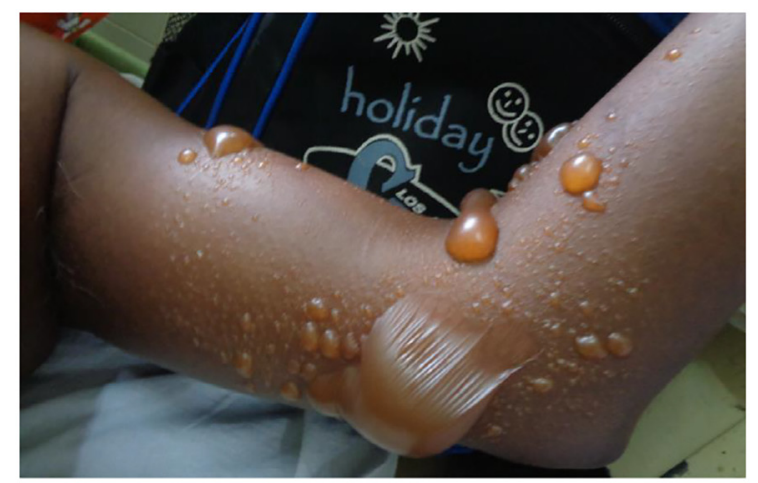

C

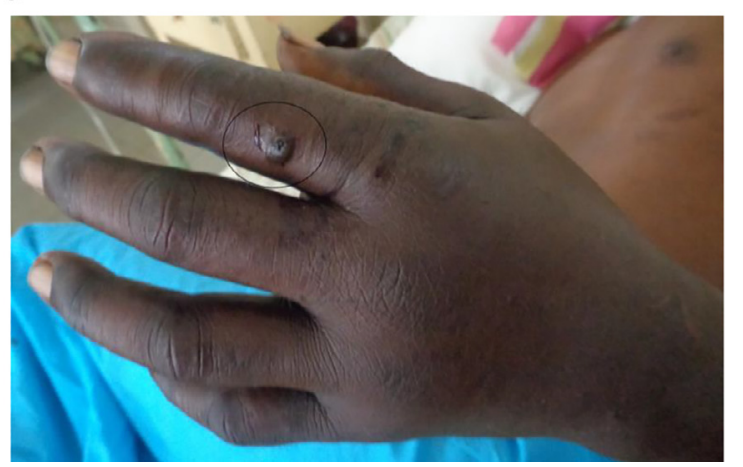

Figure 4. A and B, Multiple blisters on left upper limb on admission in case 3 patient. C, Necrosis of the site of bite: left index finger (circled).

was $229.8 \mu \mathrm{mol} \cdot \mathrm{L}^{-1}$, and renal ultrasonography showed features of chronic kidney disease (Figure 12).

\section{Discussion}

TMA is a recognized complication of some viperid and some species of Australian elapid envenomation, including the hump-nosed pit viper (H hypnale), ${ }^{8,14}$ Russell's viper (Daboia russelii), ${ }^{19}$ Saharan horned viper (Cerastes cerastes),${ }^{20}$ some species of Australian brown snakes (Pseudonaja spp), coastal taipan (Oxyuranus scutellatus), rough scale snake (Tropidechis carinatus), ${ }^{21}$ and common tiger snake (Notechis scutatus). ${ }^{22}$ It is a pathological process involving the triad of thrombocytopenia, MAHA, and microvascular occlusion due to thrombosis, leading to end organ ischemia and infarction, particularly in the kidney and brain. Thrombotic thrombocytopenic purpura (TTP) and HUS are the 2 clinical entities of TMA. In the TTP-HUS spectrum, clinically the diagnosis of TTP is favored when the neurological impairment is prominent, whereas HUS is favored when the renal impairment is prominent. ${ }^{23}$ TTP as a complication of snake envenomation has previously been reported after a hump-nosed viper bite in a 55-yold woman from Southern Province, Sri Lanka. ${ }^{24}$ TMA occurs in 3.4 to $4.6 \%$ of patients with hump-nosed viper bites. $^{8,25}$

There is a deficiency of ADAMTS13 (a disintegrin and metalloprotease with thrombospondin type 1 domains, member 13 of the family) in TMA. In secondary cases of TMA, deficiency of ADAMTS13 occurs as the result of production of auto-antibodies against this enzyme in the immune process triggered by causes such as infections, drugs, pregnancy, and cancers. However, how it occurs in snakebites remains unclear.

Snake envenomation causes venom-induced consumption coagulopathy (VICC), resulting in fibrin deposition and platelet aggregation in small vessels. These thrombi block the blood supply, causing ischemia and organ failure. ${ }^{26}$ As red blood cells travel through these damaged vessels, they are fragmented, resulting in intravascular hemolysis, which in turn causes hemolytic anemia. These fragmented red cells are seen in light microscopy of peripheral blood smears as schistocytes and helmet cells. Because of platelet aggregations, the circulating platelets decrease, resulting in thrombocytopenia. Thus, there is a positive association between VICC and TMA,${ }^{27}$ such as in our patient in case 4. Initially she had coagulopathy detected from WBCT20, and later she developed TMA. On the other hand, TMA in snakebite may occur without VICC, as in our case 1 and case 2 patients. These patients developed TMA even though WBCT20 and clotting profile were normal. How this happens is not yet understood. The traditional method of doing WBCT20 in Sri Lankan hospital settings was to use a glass tube, but recently glass tubes have been replaced with borosilicate tubes. ${ }^{28}$ The limitation of either method is lack of a control test to verify the accuracy of the measurement.

HUS is commonly seen in children and associated with severe diarrheal illness, especially in some geographic regions. It is also a type of TMA mainly caused by Shiga-like toxins produced by Shigella species or 
Table 3. Laboratory findings of patient described in case 3

\begin{tabular}{|c|c|c|c|c|c|c|c|c|c|c|c|c|c|c|c|c|c|}
\hline \multirow[b]{2}{*}{ Investigation } & \multirow[b]{2}{*}{ Reference range } & \multicolumn{16}{|c|}{ Day } \\
\hline & & 1 & 2 & 3 & 4 & 5 & 6 & 7 & 8 & 9 & 10 & 11 & 12 & 13 & 14 & 15 & 16 \\
\hline $\mathrm{WBC}\left(\times 10^{3} \cdot \mu \mathrm{L}^{-1}\right)$ & $4-10$ & 10 & 11 & 11 & 10 & 11 & 11 & 12 & 12 & 12 & 10 & 8 & 13 & 11 & & & \\
\hline Neutrophils (\%) & $50-70$ & 78 & 77 & 78 & 82 & 76 & 78 & 68 & 77 & 72 & 79 & 79 & 64 & 83 & & & \\
\hline Lymphocytes (\%) & $20-40$ & 12 & 11 & 11 & 9 & 12 & 11 & 16 & 12 & 13 & 18 & 15 & 13 & 5 & & & \\
\hline $\begin{array}{l}\text { Neutrophil count } \\
\left(\times 10^{3} \cdot \mu \mathrm{L}^{-1}\right)\end{array}$ & $2-7$ & 8 & 8 & 8 & 9 & 9 & 8 & 8 & 9 & 9 & 8 & 6 & 6 & 9 & & & \\
\hline $\begin{array}{l}\text { Lymphocyte count } \\
\qquad\left(\times 10^{3} \cdot \mu \mathrm{L}^{-1}\right)\end{array}$ & $0.8-4$ & 1 & 1 & 1 & 0.9 & 1 & 1 & 2 & 1 & 2 & 2 & 1 & 1 & 1 & & & \\
\hline $\begin{array}{l}\text { Platelets } \\
\qquad\left(\times 10^{3} \cdot \mu \mathrm{L}^{-1}\right)\end{array}$ & $150-450$ & 197 & 97 & 84 & 65 & 84 & 117 & 181 & 230 & 383 & 343 & 328 & 431 & 374 & & & \\
\hline $\mathrm{Hb}\left(\mathrm{g} \cdot \mathrm{dL}^{-1}\right)$ & $11-16$ & 12.9 & 10.7 & 9.5 & 6.9 & 6.4 & 7.3 & 6.9 & 6.9 & 7.2 & 6.8 & 6.5 & 7.2 & 7.7 & & & \\
\hline $\begin{array}{l}\text { RBC count } \\
\quad\left(\times 10^{6} \cdot \mu \mathrm{L}^{-1}\right)\end{array}$ & $4-6$ & 4 & 4 & 3 & 2 & 2 & 3 & 2 & 2 & 2 & 2 & 2 & 2 & 3 & & & \\
\hline $\operatorname{PCV}(\%)$ & $37-54$ & 40 & 32 & 26 & 21 & 17 & 21 & 19 & 20 & 21 & 20 & 19 & 21 & 22 & & & \\
\hline PT (s) & $10-15$ & $14.4 / 12$ & & $16 / 12$ & & $17 / 12$ & $25 / 12$ & $15 / 12$ & $16 / 12$ & $14 / 12$ & $15 / 12$ & & $15 / 12$ & & & & \\
\hline INR & $1-1.4$ & 1.2 & & 1.3 & & 1.4 & 2.1 & 1.3 & 1.3 & 1.2 & 1.3 & & 1.3 & & & & \\
\hline APTT (s) & $25-30$ & & & & & & $90 / 25$ & $37 / 25$ & & $30 / 25$ & & & & & & & \\
\hline $\mathrm{Na}^{+}\left(\mathrm{mmol} \cdot \mathrm{L}^{-1}\right)$ & $135-145$ & 141 & 146 & 139 & 135 & 136 & 141 & 143 & 142 & 140 & 139 & 135 & 139 & 139 & 139 & 140 & 141 \\
\hline $\mathrm{K}^{+}\left(\mathrm{mmol} \cdot \mathrm{L}^{-1}\right)$ & $3.5-4.5$ & 3.7 & 2.9 & 4.3 & 4.7 & 4.6 & 3.8 & 3.4 & 3.3 & 3.7 & 3.9 & 3.8 & 3.8 & 3.8 & 4 & 3.9 & 4 \\
\hline $\begin{array}{l}\text { Blood urea } \\
\left(\mathrm{mmol} \cdot \mathrm{L}^{-1}\right)\end{array}$ & $7.8-20.1$ & & & & & & & 20 & 20 & 20 & 11 & 12 & 13 & 14 & 11 & 9 & 12 \\
\hline $\begin{array}{l}\text { Creatinine } \\
\left(\mu \mathrm{mol} \cdot \mathrm{L}^{-1}\right)\end{array}$ & $60-115$ & 197 & 240 & 456 & 648 & 641 & 483 & 571 & 599 & 640 & 405 & 523 & 550 & 604 & 461 & 415 & 445 \\
\hline SGOT (AST) $\left(\mathrm{U} \cdot \mathrm{I}^{-1}\right)$ & $0-35$ & 87 & & & 56 & 40 & 43 & 30 & 31 & 24 & 28 & 17 & 15 & & & & \\
\hline SGPT (ALT) (U.I $\left.{ }^{-1}\right)$ & $0-45$ & 39 & & & 38 & 40 & 37 & 29 & 26 & 24 & 23 & 18 & 19 & & & & \\
\hline T. bilirubin $\left(\mu \mathrm{mol} \cdot \mathrm{L}^{-1}\right)$ & $5-21$ & & & & 32 & & & & 9 & 13 & 14 & & & & & & \\
\hline D. bilirubin $\left(\mu \mathrm{mol} \cdot \mathrm{L}^{-1}\right)$ & $0-3.4$ & & & & 16.5 & & & & & & & & & & & & \\
\hline $\operatorname{ALP}\left(U \cdot I^{-1}\right)$ & $30-120$ & & & & & & & 201 & & & & & & & & & \\
\hline MCV (fL) & $80-100$ & 93 & 88 & 87 & 86 & 84 & 83 & 84 & 86 & 86 & 86 & 86 & 89 & 86 & & & \\
\hline $\mathrm{MCH}(\mathrm{Pg})$ & $27-34$ & 30 & 29 & 32 & 29 & 32 & 29 & 30 & 30 & 31 & 29 & 30 & 30 & 30 & & & \\
\hline $\operatorname{MCHC}\left(\mathrm{g} \cdot \mathrm{dL}^{-1}\right)$ & $32-36$ & 32 & 33 & 37 & 34 & 37 & 35 & 36 & 34 & 35 & 35 & 35 & 36 & 35 & & & \\
\hline MPV (fL) & $7.8-11$ & 7.4 & 7.3 & 7.2 & 7 & & & 9.9 & 9.2 & 8.7 & 7.6 & 8.8 & 8.4 & 8.6 & & & \\
\hline
\end{tabular}

WBC, white blood cells; Hb, hemoglobin; RBC, red blood cells; PCV, packed cell volume; PT, prothrombin time; INR, international normalized ratio; APTT, activated partial thromboplastin time; SGOT, serum glutamic-oxaloacetic transaminase; AST, aspartate aminotransferase; SGPT, serum glutamic-pyruvic transaminase; ALT, alanine aminotransferase; T. bilirubin, total bilirubin; D. bilirubin, direct bilirubin; ALP, alkaline phosphatase; MCV, mean corpuscular volume; MCH, mean corpuscular hemoglobin; MCHC, mean corpuscular hemoglobin concentration; MPV, mean platelet volume. 


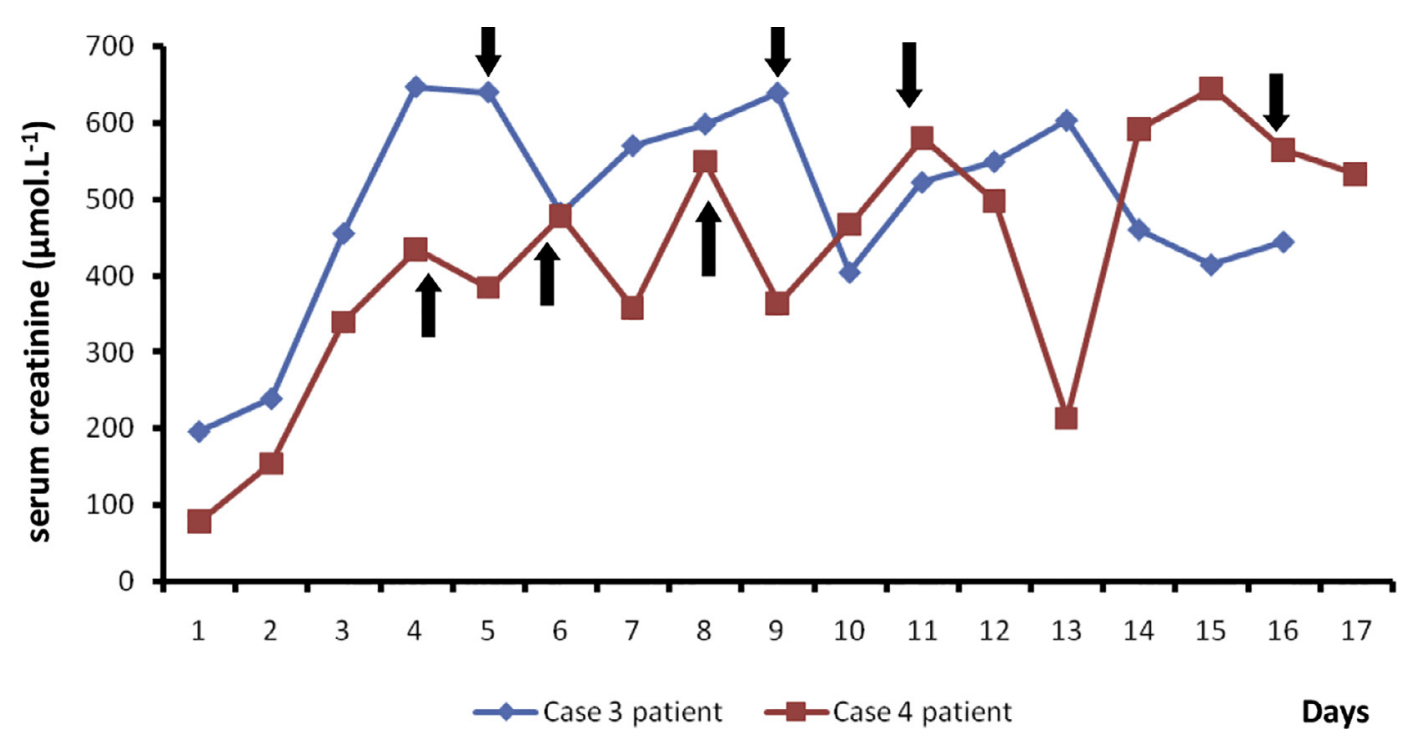

Figure 5. Changes in serum creatinine level with hemodialysis in case 3 and 4 patients. Note that; black arrows indicate the points of hemodialysis (blue line: case 3 patient; red line: case 4 patient).

Escherichia coli. In addition to its primary idiopathic childhood form, HUS may occur secondarily in children with bacterial and viral infections, in pregnancy, in the puerperium, and with oral contraceptive use. If there is a genetic defect of uncontrolled complement activation, it is called atypical hemolytic uremic syndrome. However, this syndrome can also be described in relation to snakebites. In snake envenomation, HUS is favored if there is severe involvement of renal failure, but this is not a well-understood concept. Therefore, HUS in these case histories is presumptive, and there is no direct cause and effect. Thus, this can also be considered as a type of atypical HUS or venom-induced HUS. It has previously been reported after hump-nosed pit viper, ${ }^{29}$ Russell's viper, ${ }^{30}$ and taipan envenomation. ${ }^{31}$

Our patient in case 1 spontaneously recovered with symptomatic treatment even though she developed AKI associated with microangiopathic hemolysis and had a marginal drop in platelets. She initially showed borderline normokalaemia and notable hyponatremia, most

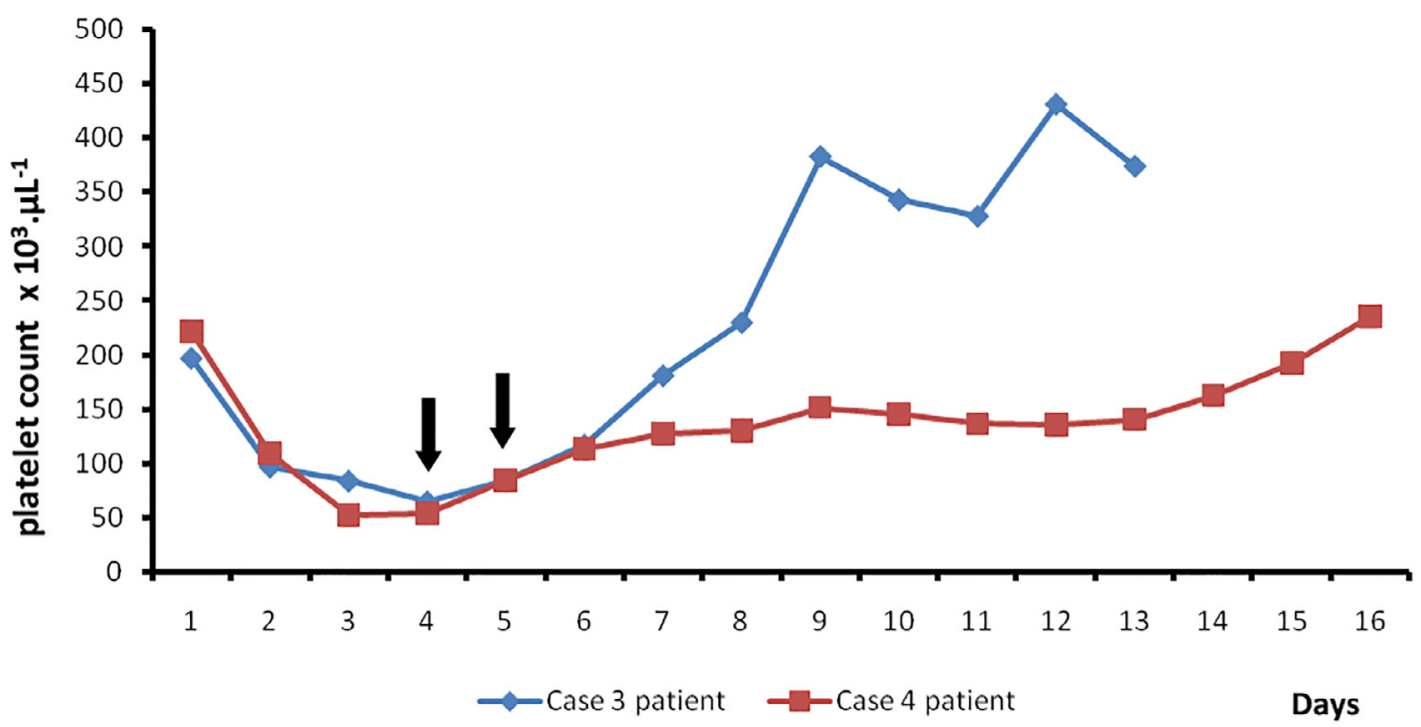

Figure 6. Daily changes in platelet counts. Black arrows indicate therapeutic plasma exchange, blue line indicates case 3 patient, and red line indicates case 4 patient. 


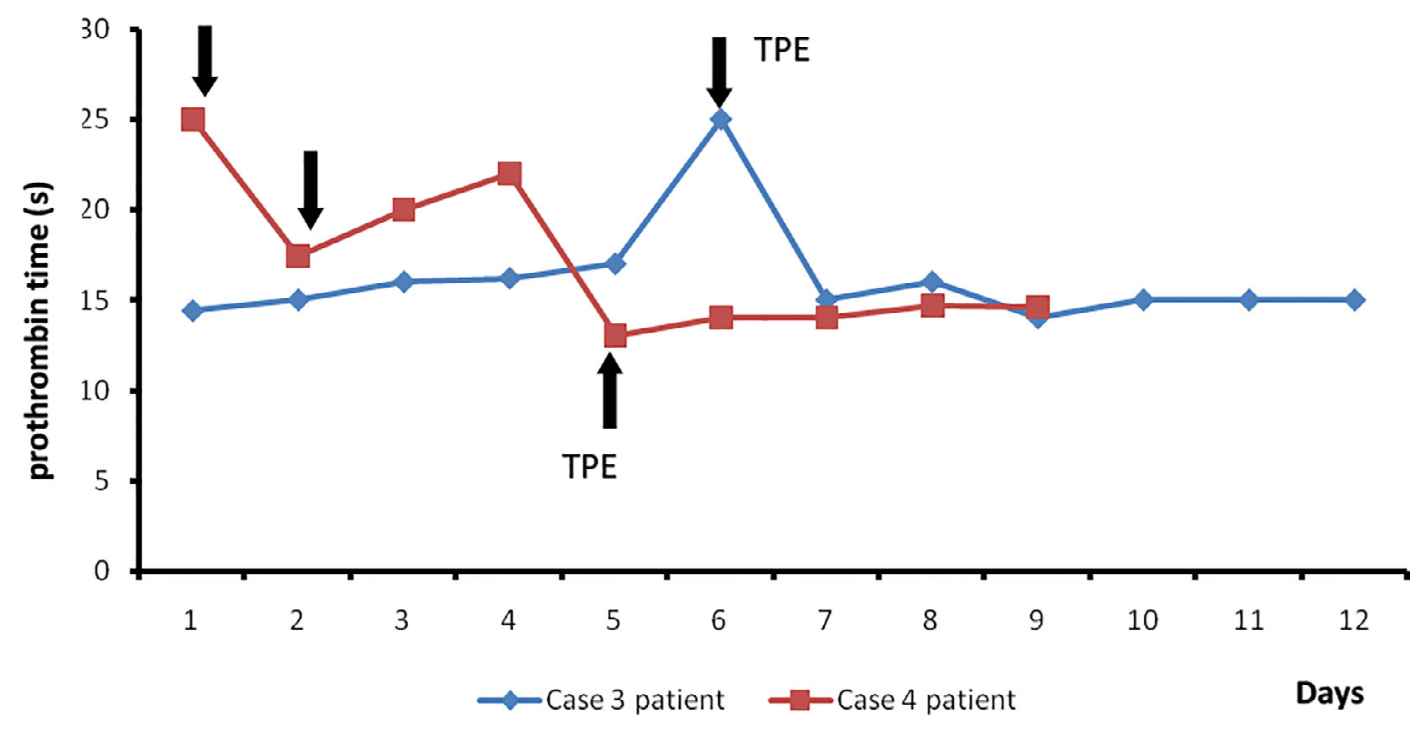

Figure 7. Daily changes in prothrombin time in case 3 and 4 patients. Black arrows indicate points of fresh frozen plasma administration in therapeutic plasma exchange (TPE), blue line indicates case 3 patient, and red line indicates case 4 patient.

likely associated with AKI, but these later improved with recovery of renal function. The patient in case 2 was anuric and did not respond to the first 2 cycles of hemodialysis. In spite of being dialyzed, his creatinine level rose, and the platelet counts did not further significantly decrease $\left(109 \times 10^{3} \cdot \mu \mathrm{L}^{-1}\right)$. With MAHA and AKI, this finding is consistent with the diagnosis of HUS. He also had very severe pain on admission. His BP was very

\section{A}

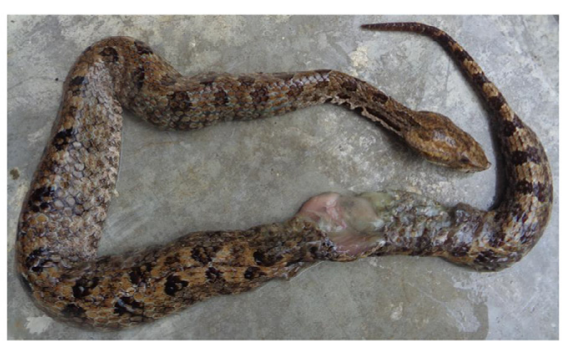

B

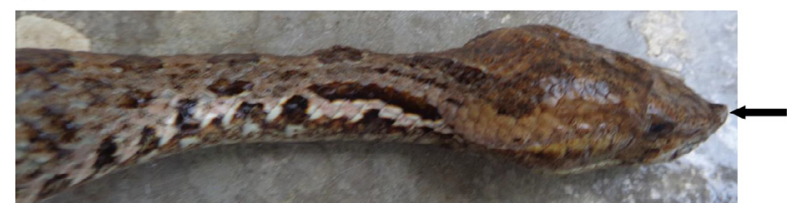

Figure 8. A, Snake responsible for the bite described in case 3. A female hump-nosed pit viper (Hypnale hypnale) with total length of $492 \mathrm{~mm}$, head length $29 \mathrm{~mm}$, tail length $72 \mathrm{~mm}$, and snout to vent length $420 \mathrm{~mm}$, from Karavita, a remote village in Ratnapura district $\left(06^{\circ} 40^{\prime} \mathrm{N} 80^{\circ} 24^{\prime} \mathrm{E}\right.$; elevation $\left.130 \mathrm{~m}[430 \mathrm{ft}]\right)$. B. The prominent tip of the snout ("hump") indicated with the black arrow is the characteristic feature of these snakes. high during the first $2 \mathrm{~d}$ and responded initially to glyceryl trinitrate infusion and then oral antihypertensive therapy (prazosin).

In hump-nosed viper bites, blisters occur usually at the site of the bite, but the patient in case 3 developed multiple blisters throughout the left upper limb that have not previously been described. In addition, his clotting derangement occurred on day 5 after snakebite (Figure 7), and his WBCT20, done $6 \mathrm{~h}$ apart, were normal for the initial $48 \mathrm{~h}$. According to the clinical and laboratory findings, HUS is the possible diagnosis in our case 2 patient because he mainly had renal impairment associated with hemolysis and thrombocytopenia.

The patient in case 4 had persistent drowsiness that lasted $4 \mathrm{~d}$ and was accompanied by a recurrent headache. However, she remained afebrile, and this is consistent with presumptive TTP. According to the analysis of $H$ hypnale venom, it is not clear how the effects of venom related to the central nervous system occur. Direct central neurotoxins of Hypnale venom have not been so far discovered, ${ }^{32}$ and also, clinically central nervous system manifestations are not seen. Therefore, persistent drowsiness and headache in the case 4 patient may be the result of secondary effects of the patient's constitutional response, as in dialysis disequilibrium syndrome (hemodialysis was started on day 4 after snakebite in this patient), or may be the consequence of autacoids in response to stress/disease (acute illness). However, in vitro tests revealed that these venoms have weak neurotoxic and mild procoagulant activity. ${ }^{33}$ Procoagulant toxins are important hemotoxins in snake venom that result in VICC. ${ }^{34}$ In $H$ hypnale venom, these 



Figure 9. Snake responsible for the bite described in case 4. A female hump-nosed pit viper (Hypnale hypnale) with total length of $375 \mathrm{~mm}$, head length $18 \mathrm{~mm}$, tail length $46 \mathrm{~mm}$, and snout to vent length $329 \mathrm{~mm}$, from Kuruvita, a remote village in Ratnapura district $\left(06^{\circ}\right.$ $40^{\prime} \mathrm{N} 80^{\circ} 24^{\prime} \mathrm{E}$; elevation $130 \mathrm{~m}$ [430 ft]).

\section{A}

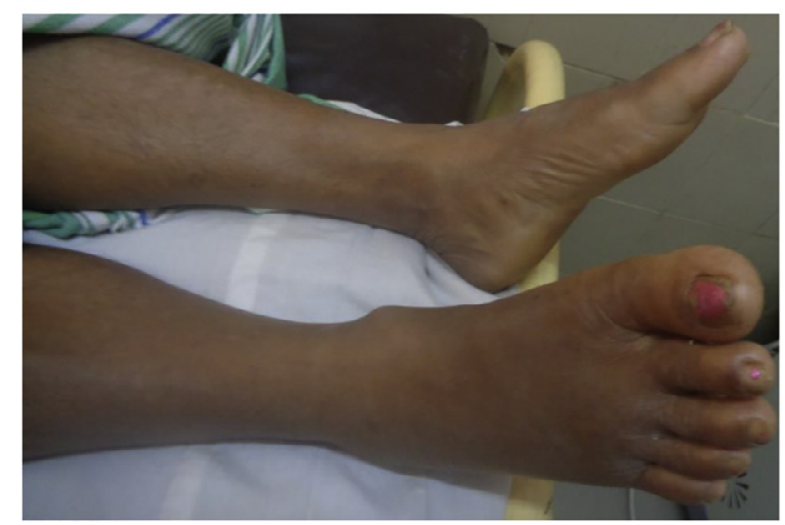

B

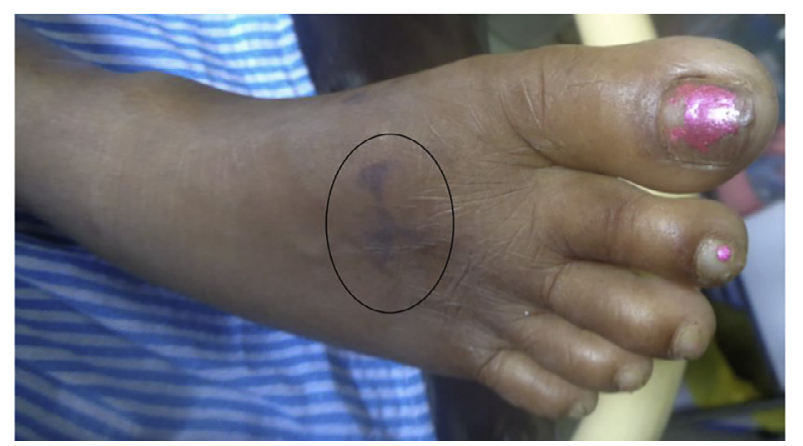

Figure 10. Bite site, right foot in patient described in case 4. A, On admission. B, On day 8 after snakebite. Note the tissue necrosis of the site of bite (circled). are thrombin-like enzymes belonging to snake venom serine proteases. One study found that snake venom serine proteases account for $3.3 \%$ of all venom composition, ${ }^{32}$ but this may vary in different geographic snake populations and possibly ontogenetically as well. Venom toxins such as snake venom metalloproteases (SVMP) may function as direct nephrotoxins by producing direct hydrolytic damage to the glomerular basement membrane.

Therapeutic plasma exchange (plasmapheresis) is a controversial issue in the management of TMA in snakebite patients, and even though there were no randomized controlled trials, it is reported that some snakebite patients with TMA have been treated with plasmapheresis without clear clinical benefit. ${ }^{14,18,22,31,35}$ In addition, there is no convincing evidence that FFP has therapeutic advantages for VICC, but we administered FFP for case 3 and 4 patients because theoretically FFP contains many clotting factors, including fibrinogen, factor V, factor VIII, and factor X, and treatment with FFP would restore the clotting cascade. On the other hand, there is risk in giving FFP because it provides additional substrate for venom procoagulant action, thus driving the prolonged generation of microthrombi, thereby aggravating the state of TMA.

Kidney injury is the most common systemic manifestation after hump-nosed pit viper bites. ${ }^{7,8,11}$ It accounts for 7.2 to $10 \%$ of all its bites ${ }^{7,8,11}$ and sometimes it may be fatal. ${ }^{13}$ Namal Rathnayaka et al observed microangiopathic hemolysis in $6.8 \%$ of envenomed patients with Hypnale spp bites, ${ }^{25}$ and all 3 species of genus Hypnale cause MAHA. ${ }^{36}$ In vivo studies using a mouse model and rabbit kidney slice model suggest possible direct nephrotoxicity because of the observation of proximal tubular cell injury and acute tubular necrosis with intact basement membrane. ${ }^{37,38}$ However, Herath et al suggest TMA as a plausible causative pathology of AKI in hump-nosed pit viper envenomation. ${ }^{14}$ Our case series also suggests that kidney involvement is probably the result of continuous glomerular ischemia secondary to renal microvasculature thrombosis. This may be clinically variable, as observed in the case 1 patient, who quickly and spontaneously recovered, in comparison with the respectively fairly slow and delayed recovery of the case 2 and 3 patients. However, the patient in case 4 probably had occult pre-existing chronic kidney disease (diabetic nephropathy), experienced a greater renal insult from the envenomation, and thus required renal replacement therapy. Therefore, her postenvenomation chronic kidney disease may have been purely a complication of her poorly managed diabetes, which was aggravated by the Hypnale envenomation. This case series conveys the severity and unpredictability of complications and morbidities of hump-nosed pit viper envenomation and the urgent need for antivenom in Sri Lanka to effectively manage these seriously 
Table 4. Laboratory findings of patient described in case 4

\begin{tabular}{|c|c|c|c|c|c|c|c|c|c|c|c|c|c|c|c|c|c|}
\hline \multirow[b]{2}{*}{ Investigation } & \multirow[b]{2}{*}{ Reference range } & \multicolumn{16}{|c|}{ Day } \\
\hline & & 1 & 2 & 3 & 4 & 5 & 6 & 7 & 8 & 9 & 10 & 11 & 12 & 13 & 14 & 15 & 16 \\
\hline $\operatorname{WBC}\left(\times 10^{3} \cdot \mu \mathrm{L}^{-1}\right)$ & $4-10$ & 11 & 13 & 15 & 14 & 10 & 11 & 11 & 12 & 17 & 22 & 19 & 16 & & 12 & 12 & 7 \\
\hline Neutrophils (\%) & $50-70$ & 82 & 84 & 80 & 85 & 80 & 77 & 74 & 73 & 70 & 71 & 76 & 74 & & 74 & 76 & 69 \\
\hline Lymphocytes (\%) & $20-40$ & 15 & 10 & 15 & 11 & 16 & 15 & 18 & 19 & 20 & 21 & 15 & 16 & & 16 & 15 & 20 \\
\hline $\begin{array}{l}\text { Neutrophil count } \\
\left(\times 10^{3} \cdot \mu \mathrm{L}^{-1}\right)\end{array}$ & $2-7$ & 9 & 11 & 12 & 12 & 8 & 8 & 8 & 9 & 12 & 16 & 14 & 12 & & 9 & 9 & 5 \\
\hline $\begin{array}{l}\text { Lymphocyte count } \\
\qquad\left(\times 10^{3} \cdot \mu \mathrm{L}^{-1}\right)\end{array}$ & $0.8-4$ & 2 & 2 & 2 & 2 & 1 & 2 & 2 & 2 & 3 & 5 & 3 & 3 & & 2 & 2 & 1 \\
\hline Platelets $\left(\times 10^{3} \cdot \mu \mathrm{L}^{-1}\right)$ & $150-450$ & 221 & 109 & 52 & 54 & 84 & 113 & 127 & 130 & 151 & 145 & 136 & 135 & & 162 & 192 & 235 \\
\hline $\mathrm{Hb}\left(\mathrm{g} \cdot \mathrm{dL}^{-1}\right)$ & $11-16$ & 10.6 & 8.9 & 7.8 & 6.9 & 6.5 & 6.4 & 8.5 & 7.9 & 7.5 & 6.6 & 7.8 & 7.8 & & 7.1 & 7 & 6.7 \\
\hline $\begin{array}{l}\text { RBC count } \\
\left(\times 10^{6} \cdot \mu \mathrm{L}^{-1}\right)\end{array}$ & $4-6$ & 4 & 3.5 & 3 & 3 & 2.5 & 2 & 3 & 3 & 3 & 2 & 3 & 3 & & 2.5 & 2.5 & 2 \\
\hline $\operatorname{PCV}(\%)$ & $37-54$ & 33 & 28 & 23 & 20 & 19 & 18 & 25 & 23 & 22 & 20 & 23 & 23 & & 21 & 21 & 21 \\
\hline PT (s) & $10-15$ & $25 / 12$ & $17.4 / 12$ & $20 / 12$ & $22 / 12$ & $13 / 12$ & $14 / 12$ & $14 / 12$ & $14.7 / 12$ & $14.6 / 12$ & & & & & & $15.4 / 12$ & \\
\hline INR & $1-1.4$ & 2.1 & 1.5 & 1.7 & 1.9 & 1.1 & 1.2 & 1.2 & 1.2 & 1.2 & & & & & & 1.3 & \\
\hline APTT (s) & $25-30$ & $43 / 25$ & $29 / 25$ & $28 / 25$ & $>60$ & $27 / 25$ & $30 / 25$ & $22 / 25$ & & & & & & & & & \\
\hline $\mathrm{Na}^{+}\left(\mathrm{mmol} \cdot \mathrm{L}^{-1}\right)$ & $135-145$ & 142 & 137 & 141 & 136 & 136 & & & & 135 & 132 & 131 & 135 & 133 & 132 & 134 & 134 \\
\hline $\mathrm{K}^{+}\left(\mathrm{mmol} \cdot \mathrm{L}^{-1}\right)$ & $3.5-4.5$ & 3.8 & 4 & 3.5 & 3.6 & 3.3 & & & & 3.6 & 3.9 & 3.8 & 3.6 & 4.1 & 4.2 & 4.1 & 4.3 \\
\hline Blood urea $\left(\mathrm{mmol} \cdot \mathrm{L}^{-1}\right)$ & $2.2-8.2$ & 3 & 4 & 12 & 20 & 19 & & 15 & 21 & 13 & & & & & & & \\
\hline Creatinine $\left(\mu \mathrm{mol} \cdot \mathrm{L}^{-1}\right)$ & $60-115$ & 79 & 155 & 340 & 435 & 385 & 478.9 & 358 & 550 & 365 & 468 & 581 & 498 & 214 & 593 & 646 & 565 \\
\hline SGOT (AST) $\left(\mathrm{U} \cdot \mathrm{I}^{-1}\right)$ & $0-35$ & & 108 & 364 & 130 & ND & 46 & & 24 & & & & & & 15 & & \\
\hline SGPT (ALT) $\left(U \cdot I^{-1}\right)$ & $0-45$ & & 55 & 110 & 98 & & 44 & & 31 & & & & & & 6 & & \\
\hline T. bilirubin $\left(\mu \mathrm{mol} \cdot \mathrm{L}^{-1}\right)$ & $5-21$ & & 35 & 107 & 92 & 31 & & 45 & 16 & 13 & & & & & & & \\
\hline D. bilirubin $\left(\mu \mathrm{mol} \cdot \mathrm{L}^{-1}\right)$ & $0-3.4$ & & 9 & 63 & 77 & 29 & & 38 & 13 & 9 & & & & & & & \\
\hline MCV (fL) & $80-100$ & 84 & 82 & 80 & 77 & 79 & 77 & 79 & 79 & 79 & 81 & 83 & 82 & & 84 & 85 & 87 \\
\hline $\mathrm{MCH}(\mathrm{Pg})$ & $27-34$ & 27 & 26 & 27 & 27 & 27 & 28 & 27 & 27 & 27 & 27 & 28 & 28 & & 28 & 28 & 29 \\
\hline $\operatorname{MCHC}\left(\mathrm{g} \cdot \mathrm{dL}^{-1}\right)$ & $32-36$ & 32 & 31 & 34 & 34 & 34 & 36 & 34 & 34 & 35 & 34 & 34 & 34 & & 33 & 33 & 33 \\
\hline MPV (fL) & $7.8-11$ & 8.7 & 7.4 & 7.4 & 7.9 & 9.5 & 8.6 & 9.2 & 9 & 8.9 & 9 & 9.4 & 9.1 & & 9.4 & 8.3 & 7.9 \\
\hline $\mathrm{CRP}\left(\mathrm{mg} \cdot \mathrm{L}^{-1}\right)$ & $<6$ & 5 & & 281 & 484 & 187 & & & & & 68 & 50 & 27 & 15 & 14 & 6 & \\
\hline Total protein $\left(\mathrm{g} \cdot \mathrm{L}^{-1}\right)$ & $61-77$ & & & & & & 53 & & 53 & & & & & 49 & & & \\
\hline $\operatorname{Albumin}\left(\mathrm{g} \cdot \mathrm{L}^{-1}\right)$ & $36-48$ & & & & & & 30 & & 28 & & & & & 27 & & & \\
\hline Blood picture & & & МАHA & MAHA & MAHA & & MAHA & & & & & & & & & & \\
\hline
\end{tabular}

WBC, white blood cells; Hb, hemoglobin; RBC, red blood cells; PCV, packed cell volume; SGOT, serum glutamic-oxaloacetic transaminase; AST, aspartate aminotransferase; SGPT, serum glutamic-pyruvic transaminase; ALT, alanine aminotransferase; T. bilirubin, total bilirubin; D. bilirubin, direct bilirubin; MCV, mean corpuscular volume; MCH, mean corpuscular hemoglobin; MCHC, mean corpuscular hemoglobin concentration; MPV, mean platelet volume; CRP, C-reactive protein; MAHA, microangiopathic hemolytic anemia. 
A



B

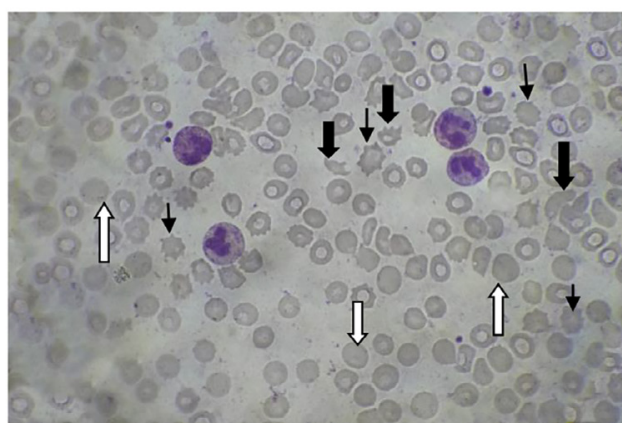

Figure 11. Blood picture $20 \mathrm{~h}$ after the snakebite in case 4 patient, showing fragmented erythrocytes (indicated with wide black arrows), polychromatics (indicated with white arrows), and acanthocytes (indicated with narrow black arrows). A, $\times 40 ; \mathrm{B}, \times 100$.
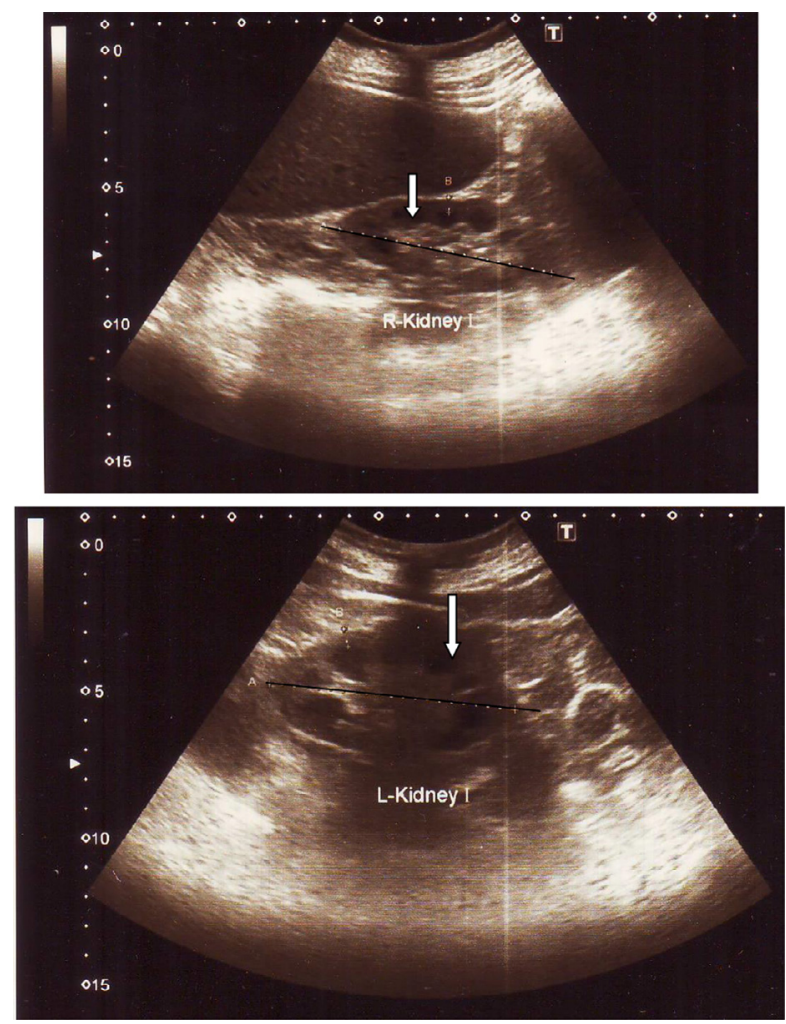

Figure 12. Ultrasonography of bilateral kidneys (done 4 months after the snakebite) in case 4 patient. Note the features of chronic kidney disease: small, shrunken kidneys (indicated in black axis), decreased corticomedullary demarcation (indicated with white arrow) and increased renal echogenicity.

envenomed patients. Although Instituto Clodomiro Picado (San Jose, Costa Rica) anti-H hypnale monovalent antivenom is being trialed in Sri Lanka, it is currently unavailable in nonenrolled medical facilities throughout the country.
Acknowledgments: The Consultant Physicians and staff of medical wards in Provincial General Hospital, Ratnapura, Sri Lanka, are acknowledged. Dr Radha Jayathunga (consultant hematologist, Provincial General Hospital, Ratnapura) is acknowledged for the interpretation of peripheral blood pictures. Written consent for publication of these case histories and photographs was obtained from the patients.

Author Contributions: Patient management involvement (RMMKNR, PEANR); literature search (RMMKNR, PEANR); snake handling and morphological feature identification (RMMKNR); drafting of the manuscript (RMMKNR, SAMK, PEANR); writing of case histories (RMMKNR, SAMK, PEANR); review and approval of the final manuscript (RMMKNR, SAMK, PEANR).

Financial/Material Support: None.

Disclosures: None

\section{References}

1. De Silva A, Ranasinghe L. Epidemiology of snake-bite in Sri Lanka: a review. Ceylon Med J. 1983;28(3):144-54.

2. De Silva A. Snake bites in Anuradhapura District. The Snake. 1981;13(2):117-310.

3. Kasturiratne A, Wickremasinghe AR, de Silva N, Gunawardena NK, Pathmeswaran A, Premaratna R. et al. The global burden of snakebite: a literature analysis and modeling based on regional estimates of envenoming and deaths. PLoS Med. 2008;5(11):e218.

4. Maduwage K, Silva A, Manamendra-Arachchi K, Pethiyagoda RA. A taxonomic revision of the South Asian humpnosed pit vipers (Squamata: Viperidae: Hypnale). Zootaxa. 2009;2232:1-28.

5. Sellahewa KH, Kumararatne MP. Envenomation by the hump-nosed Viper (Hypnale hypnale). Am J Trop Med Hyg. 1994;51(6):823-5.

6. Namal Rathnayaka RMMK, Kularatne SAM, Rajapakshe RPVJ, Ranasinghe JGS, Ranathunga PEAN. Epidemiology and clinical manifestations of Hump-nosed pit viper (Genus: Hypnale) envenomation. In: Proceedings of Peradeniya University International Research Sessions (iPURSE). Sri Lanka. University of Peradeniya; 2015:219. November 5-6. 
7. Ariaratnam CA, Thuraisingam V, Kularatne SA, Sheriff MH, Theakston RD, de Silva A. et al. Frequent and potentially fatal envenoming by hump-nosed pit vipers (Hypnale hypnale and $H$ nepa) in Sri Lanka: lack of effective antivenom. Trans R Soc Trop Med Hyg. 2008;102(11):1120-6.

8. Namal Rathnayaka RMMK, Kularatne SAM, Ranathunga PEAN, Rajapakse RPVJ, Ranasinghe JGS. Species specific clinical manifestations following Hump-nosed pit viper (Genus: Hypnale) envenoming in Sri Lanka. Ceylon Med J. 2017;62(Suppl. 1):97.

9. WHO Expert Committee on Biological Standardization. WHO Guidelines for the production control and regulation of snake antivenom immunoglobulins. WHO Technical Report Series. Geneva, Switzerland: WHO; 2010: 1-134.

10. Premawardena AP, Seneviratne SL, Gunatilake SB, De Silva HJ. Excessive fibrinolysis: the coagulopathy following Merrem's hump-nosed viper (Hypnale hypnale) bites. Am J Trop Med Hyg. 1998;58(6):821-3.

11. Namal Rathnayaka RMMK, Kularatne SAM, Rajapakshe RPVJ, Ranasinghe JGS, Ranathunga PEAN. Kidney injury following hump nosed pit viper (Genus: Hypnale) envenomation. In: Proceedings of International Conference in Tropical Medicine. Peradeniya, Sri Lanka. University of Peradeniya; 2015:52. December 10-11.

12. Kularatne SAM, Ratnatunga N. Severe systemic effects of Merrem's hump-nosed viper bite. Ceylon Med J. 1999;44 (4):169-70.

13. Namal Rathnayaka RMMK, Ranathunga PEAN. Acute kidney injury which leads to chronic kidney disease and death following hump nosed pit viper (Genus: Hypnale) envenoming. J Ratnapura Clin Soc. 2016;11:40-2.

14. Herath N, Wazil A, Kularatne S, Ratnatunga N, Weerakoon $\mathrm{K}$, Badurdeen $\mathrm{S}$, et al. Thrombotic microangiopathy and acute kidney injury in hump-nosed viper (Hypnale species) envenoming: a descriptive study in Sri Lanka. Toxicon. 2012;60(1):61-5.

15. Dharmaratne L, Gunawardena U. Generalized bleeding tendency and acute renal failure following Merrem's hump-nosed viper bite. J Ceylon Coll Physic. 1988;21-22: 37-42. -89 .

16. Thillainathan S, Priyangika D, Marasinghe I, Kanapathippillai K, Premawansa G. Rare cardiac sequelae of a hump nosed viper bite. BMC Res Notes. 2015;8:437.

17. Jeevagan V, Chang T, Ghanathasan AC. Acute ischemic stroke following hump-nosed viper envenoming; first authenticated case. Thromb J. 2012;10(1):21.

18. Namal Rathnayaka RMMK, Nishanthi Ranathunga PEA, Ranaweera Janaka, Jayasekara Krishantha, Kularatne SAM. Cardiac arrest and atrial fibrillation following humpnosed pit viper (Hypnale hypnale) envenoming. Toxicon. 2018;148:33-9.

19. Kularatne SAM, Wimalasooriya S, Nazar K, Maduwage K. Thrombotic microangiopathy following Russell's viper (Daboia russelii) envenoming in Sri Lanka: a case report. Ceylon Med J. 2014;59:29-30.

20. Schneemann M, Cthomas R, Laidlaw ET, El Nahas AM, Theakston RD, Warrell DA. Life-threatening envenoming by the Saharan horned viper (Cerastes cerastes) causing microangiopathic haemolysis, coagulopathy and acute renal failure: clinical cases and review. QJM. 2004;97(11):717-27.

21. Isbister GK, Little M, Cull G, McCoubrie D, Lawton P, Szabo F. et al. Thrombotic microangiopathy from Australian brown snake (Pseudonaja) evenoming. Intern Med J. 2007;37(8):523-8.

22. Casamento AJ, Isbister GK. Thrombotic microangiopathy in two tiger snake envenomations. Anaesth Intensive Care. 2011;39(6):1-4.

23. Shenkman B, Einav Y. Thrombotic thrombocytopenic purpura and other thrombotic microangiopathic hemolytic anemias: diagnosis and classification. Autoimmun Rev. 2014;13(4-5):584-6.

24. Withana M, Rodrigo C, Gnanathasan A, Gooneratne L. Presumptive thrombotic thrombocytopenic purpura following a hump-nosed viper (Hypnale hypnale) bite: a case report. J Venom Anim Tox Inclu Trop Dis. 2014;20:26.

25. Namal Rathnayaka RMMK, Nishanthi Ranathunga PEA, Kularatne SAM, Radha Jayathunga, Kumarasinghe KDM, Jeganadan K. Epidemiology and haematological manifestations following hump-nosed pit viper (Genus: Hypnale) envenoming in the region of Ratnapura (Sabaragamuwa Province wet zone of Sri Lanka). J Ratnapura Clin Soc. 2017;11:30-8.

26. Than-Than, Francis N, Tin-Nu-Swe, Myint-Lwin, Tun-Pe, Phillips RE, et al. Contribution of focal haemorrhage and microvascular fibrin deposition to fatal envenoming by Russell's viper (Vipera russelli siamensis) in Burma: clinicopathological studies. Acta Tropica. 1989;46(1):23-38.

27. Isbister GK. Snakebite doesn't cause disseminated intravascular coagulation: coagulopathy and thrombotic microangiopathy in snake envenoming. Semin Throm Hemost. 2010;36(4):444-51.

28. Ratnayake I, Shihana F, Dissanayake DM, Buckley NA, Maduwage K, Isbister GK. Performance of the 20-minute whole blood clotting test in detecting venom induced consumption coagulopathy from Russell's viper (Daboia russelii) bites. Thromb Haemost. 2017;117(3):500-7.

29. Mitrakrishnan JY, Bandula CW, Mitrakrishnan CS, Somaratna K, Jeyalakshmy S. Haemolytic uremic syndrome a hitherto unreported complication of hump-nosed viper envenomation. Indian J Hematol Blood Transfus. 2013;29 (2):116-8.

30. Date Anand, Pulimood R, Jacob CK, Kirubakaran MG, Shastry JCM. Haemolytic-rraemic syndrome complicating snake bite. Nephron. 1986;42(1):89-90.

31. Cobcroft RG, Williams A, Cook D, Williams DJ, Masci P. Hemolytic uremic syndrome following taipan envenomation with response to plasmapheresis. Pathology. 1997;29 (4):399-402.

32. Tan CH, Tan NH, Sim SM, Fung SY, Gnanathasan CA. Proteomic investigation of Sri Lankan hump-nosed pit viper (Hypnale hypnale) venom. Toxicon. 2015;93:164-70.

33. Maduwage K, Hodgson WC, Konstantakopoulos N, O'Leary MA, Gawarammana I, Isbister GK. The in vitro toxicity of venoms from South Asian Hump-nosed pit vipers (Viperidae: Hypnale). J Venom Res. 2011;2:17-23. 
34. Isbister GK. Procoagulant snake toxins: laboratory studies, diagnosis, and understanding snake bite coagulopathy. Semin Throm Hemost. 2009;35(1):93-103.

35. Namal Rathnayaka RMMK, Nishanthi Ranathunga PEA, Kularatne SAM. Therapeutic plasma exchange (plasmapheresis) for the treatment of hump-nosed pit viper (Hypnale spp) envenoming. J Ratnapura Clin Soc. 2018;3:20-6.

36. Namal Rathnayaka RMMK, Nishanthi Ranathunga PEA, Kularatne SAM, Rajapakse RPVJ, Ranasinghe JGS, Jayathunga Radha. Microangiopathic haemolytic anaemia following three different species of hump-nosed pit viper (Genus: Hypnale) envenoming in Sri Lanka. Wilderness Environ Med. 2018;29(1):94-101.

37. Silva A, Gunawardena P, Weilgama D, Maduwage K, Gawarammana I. Comparative in-vivo toxicity of venoms from South Asian hump-nosed pit vipers (Viperidae: Crotalinae: Hypnale). BMC Res Notes. 2012;5:471.

38. Gunatilake M, Jayakody RL, Angunawela P, Tissera de A. Direct nephrotoxic effects produced by venoms of Sri Lankan cobra, Russell's viper and hump nosed viper. Ceylon J Med Sci. 2003;46:61-6. 